Case report

\title{
Kounis syndrome due to deksketoprofen trometamol administration is
}

\author{
İbrahim Ethem Dural ${ }^{\mathrm{a}}$, Sadık Volkan Emren ${ }^{\mathrm{b}, *}$, Ersel Onrat ${ }^{\mathrm{c}}$ \\ a Afyon Kocatepe University, School of Medicine, Department of Cardiology, Afyonkarahisar, Turkey \\ ${ }^{\mathrm{b}}$ Afyonkarahisar State Hospital Department of Cardiology, Afyonkarahisar, Turkey \\ c Afyon Kocatepe University, School of Medicine, Department of Cardiology, Afyonkarahisar, Turkey
}

\section{A R T I C L E I N F O}

\section{Article history:}

Received 14 December 2016

Received in revised form 4 January 2017

Accepted 5 January 2017

Available online 21 February 2017

\section{Keywords:}

Koinus syndrome

Vasospastic angina

Deksketoprofen trometamol

\begin{abstract}
A B S T R A C T
Kounis syndrome is a rarely seen syndrome which is also called allergic angina syndrome. Contacted allergic agents cause allergic reaction, and then it leads to vasospastic angina pectoris or myocardial infarction. When the patient contact allergic agent, histamine releases from mast cells, and vasospasm or plaque rupture occurs at coronary arteries. A lot of allergic agents is defined which causes Koinus syndrome. Most of these allergic agents are antibiotics, analgesics, antineoplastics, contrast agents, anethesics, non-steroid antiinflammatory drugs, proton pump inhibitors and venoms. Our patient is the first case report which is the Kounis syndrome after taking deksketoprofen trometamol.

(c) 2017 The Society of Cardiovascular Academy. Production and hosting by Elsevier B.V. This is an open access article under the CC BY-NC-ND license (http://creativecommons.org/licenses/by-nc-nd/4.0/).
\end{abstract}

\section{Introduction}

Imbalance of myocardial oxygen supply and demand cause myocardial ischemia which leads to development of angina pectoris. One of the reasons of myocardial ischemia is coronary vasospasm which is resulted from the contraction of epicardial coronary arteries. If coronary vasospasm become longer, it may causes myocardial infarction.

Myocardial ischemia or infarction is sometimes occurred due to allergic agents. This entity is defined as allergic angina syndrome which is also called Kounis syndrome by Kounis and Zafras at $1991,{ }^{1}$ After contacting with allergens, inflammatory mediators like histamine and leukotriens, releasing from mast cells, causes vasospasm or plaque rupture of coronary artery. Plaque rupture, vasospasm and thrombus of coronary arteries cause myocardial ischemia and myocardial infarction,, ${ }^{2,3}$ Histamine is an important biochemical mediator and its effects via $\mathrm{H} 1$ histamine receptors at smooth muscle cells and coronary arteries,. ${ }^{4}$ The other reasons of allergic ischemia are collagen destruction and plaque rupture, caused by metalloprotein activators like triptase and kimase, ${ }^{4,5}$

In this paper we present a case developing vasospastic angina pectoris after taking deksketoprofen trometamol.

\footnotetext{
is Peer review under responsibility of The Society of Cardiovascular Academy.

* Corresponding author at: Afyonkarahisar State Hospital Department of Cardiology, Afyonkarahisar Post code: 03000, Turkey.

E-mail address: vemren@hotmail.com (S.V. Emren).
}

\section{Case}

A 49-year-old man admitted to emergency department with a complaint of itching and angina pectoris. His symptoms had begun $30 \mathrm{~min}$ after taking $25 \mathrm{mg}$ deksketoprofen trometamol for his headache. On admission patient's blood pressure was $110 / 70 \mathrm{mmHg}$ and heart rate was 86 pulse/min. There was no abnormality on his cardiovascular and other system examinations. He had an only allergy anamnesis for shaving foam. He was a smoker ( 35 years; 20 pieces/day). At emergency department, $5 \mathrm{mg}$ intravenous feniramine and intravenous $20 \mathrm{mg}$ methyl prednizolone had been administrated as a first intervention for his itch. Since the patient had also angina pectoris we performed twelve derivations electrocardiogram (ECG) which revealed ST segment elevation in inferior derivations (D2, D3, aVF),(Fig. 1). However ST segment elevation had disappeared while he was transferring to cardiology clinic (Fig. 2). Patient was hospitalized at coronary intensive care unit for medical treatment.

There was no abnormality in biochemical and cardiac markers and transthoracic echocardiography revealed $60 \%$ ejection fraction with no segmental motion abnormality. Coronary angiography was demonstrated that there were some plaques on left anterior descending artery, circumflex artery, and right coronary artery (RCA) (Fig. 3a). In this context we thought that, the patient's clinic was vasospastic angina and we performed ergonovine test to evaluate vasospastic angina pectoris diagnosis. We gave $10 \mu \mathrm{g}$ and $20 \mu \mathrm{g}$ methyl ergonovine to the right coronary artery because of ST elevation on inferior derivations. Patient described chest pain and pressure on his chest, after giving $20 \mu \mathrm{g}$ methylergonovine. We performed an ECG and there was ischemic T wave negativity on inferior derivations. Simultaneously coronary angiography showed the vasospasm on RCA (Fig. 3b).Intravenous nitroglycerine was given and then his symptoms and ECG findings were disappeared. 


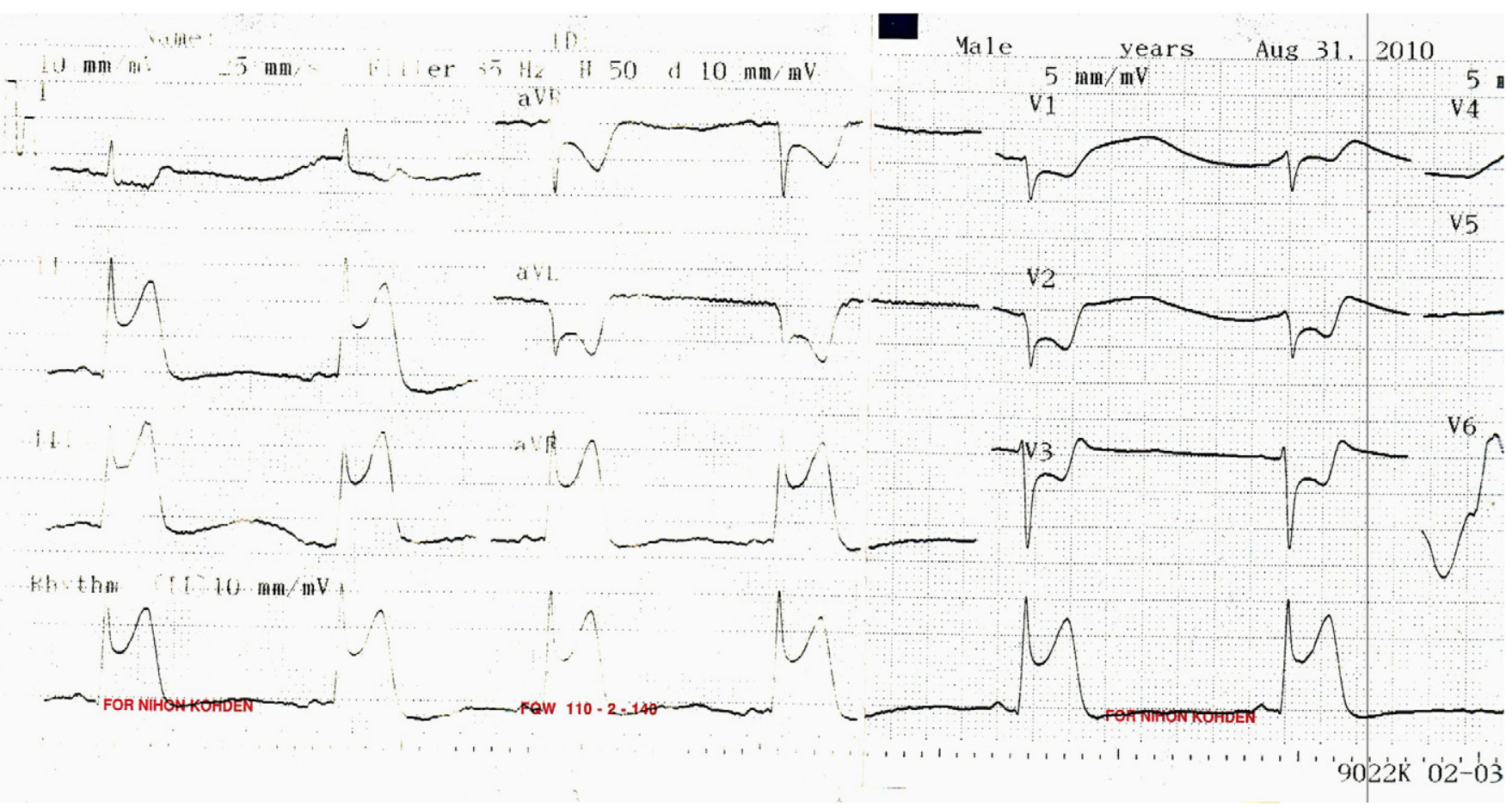

Fig. 1. Electrocardiogram revealed ST segment elevation in inferior derivations after taking $25 \mathrm{mg}$ deksketoprofen trometamol.

\section{Discussion}

Kounis syndrome called as "allergic angina syndrome" was first described by Kounis and Zarvas in $1991 .{ }^{1}$ Kounis syndrome is mostly seen in elderly patients Most of whom have an atopy history.

After contacting with allergens (drugs, venom, etc....), antigene or antigene-anticore complex causes mast cell activation or type 1 anaphylaxis. Histamine, neutral protease (kimase, tripase), asite hidrolase and platelet activated factors are released from mast cells following allergic reaction. These chemical mediators lead to hypotension, vascular collapse, tachycardia, ventricular arrhythmia, vasospasm on coronary arteries and plaque rupture on cardiovascular system which ultimately result in myocardial infarction or cardiac arrest,. ${ }^{4}$
There are two types of Kounis syndrome. Type 1 Kounis Syndrome is seen in patients with normal coronary arteries and low cardiovascular risk factors,. ${ }^{2}$ Whereas type 2 Kounis syndrome generally seen in patients having coronary heart disease or plaque on coronary arteries. Cardiac markers may increase in both types. Myocardial damage is generally developed on inferior wall at Kounis syndrome but anterior wall may be affected as well. ${ }^{5}$

Antibiotics, analgesics (aspirin, dipyrone), antineoplastics, contrast agents, corticosteroids, anesthetics, thrombolytics, anticoagulants, proton pump inhibitors, Skin disinfectants, bee and snake venoms may cause Kounis syndrome. Non-steroid antiinflammatory drugs (alclofenac, diclofenac, naproxen) can also cause Kounis syndrome. Majority of the cases with Kounis syndrome have an atopy history. ${ }^{2}$ Our

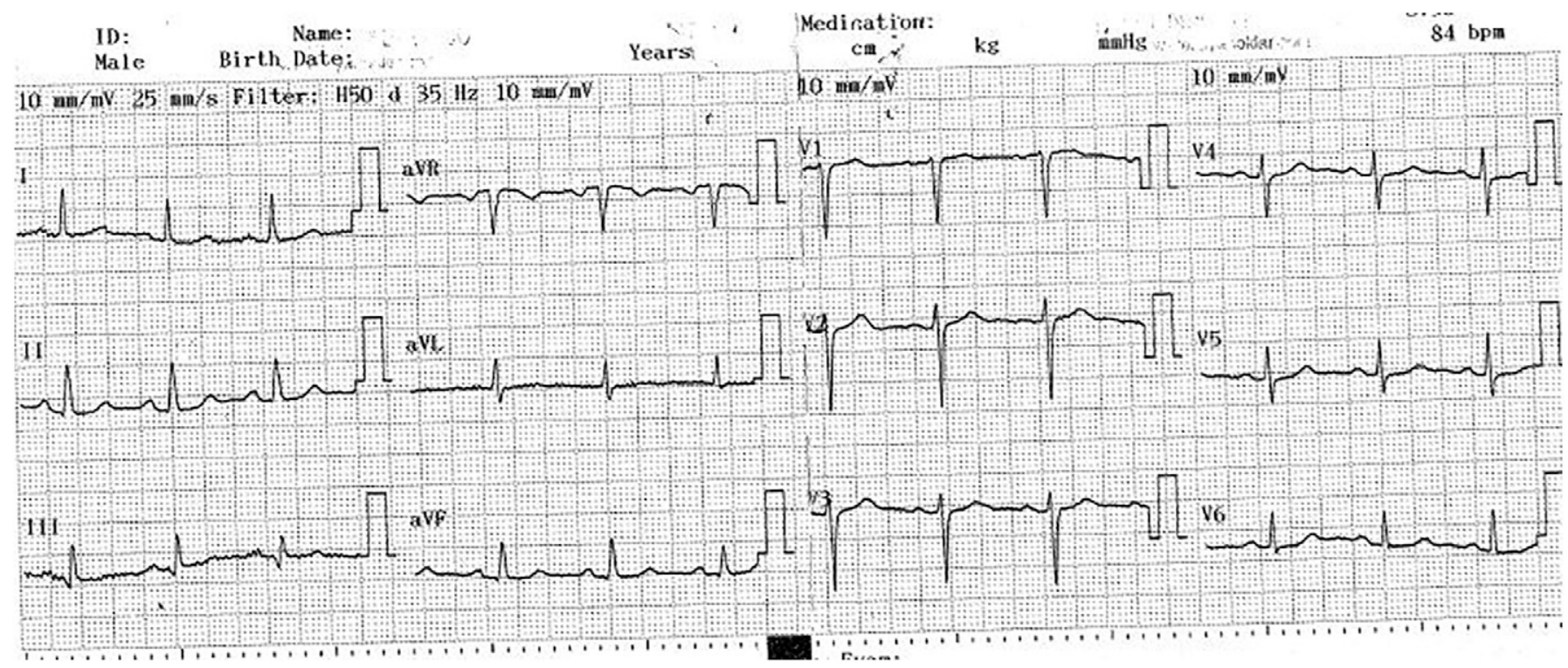

Fig. 2. Electrocardiogram revealed ST segment resolution following the treatment of the allergic reaction. 


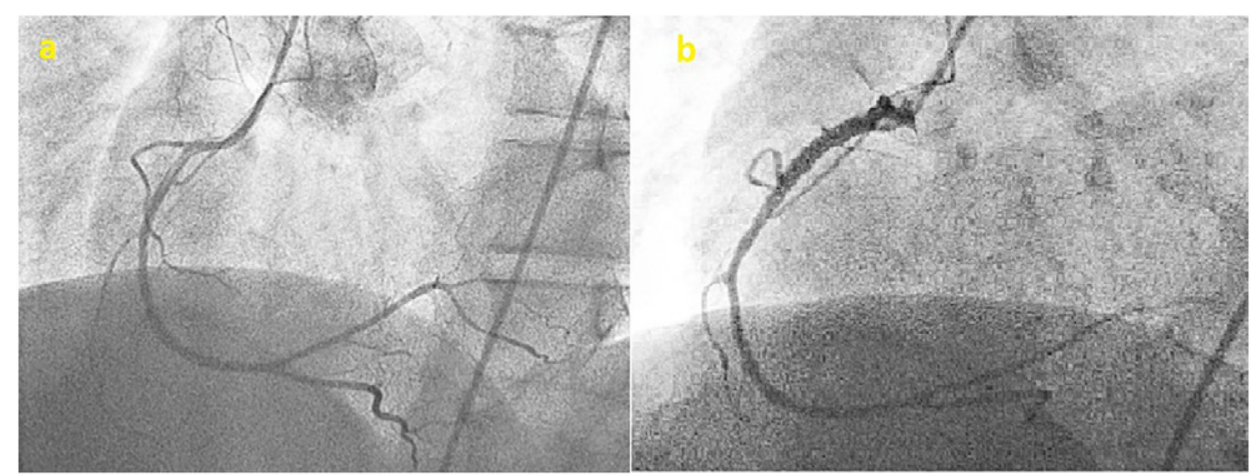

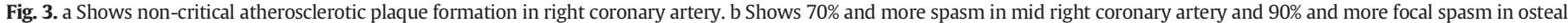
posterior descending and posterolateral branch of right coronary arter artery following ergonovine administration.

case has been the first reported Kounis syndrome due to deksketoprofen trometamol which is the member of non-steroid antiinflammatory drugs.

After definite diagnosis, treatment should be directed to the reason and treatment should be targeted to the allergic reaction.

In this case, we thought Kounis syndrome because of his symptoms began after taking deksketoprofen trometamol. He has an atopy history (shaving foam) also. He had itching all of his body, nausea, dizziness associated with anaphylaxis after taking deksketoprofen trometamol. Simultaneously patient has described typical angina pectoris and there was inferior ST segment elevation on ECG. ST elevation disappeared after taking intravenous feniramine and intravenous methyl prednizolone. Cardiac markers did not increase. We saw vasospasm on right coronary arteries and $\mathrm{T}$ wave negativity at ergonovin test. These findings confirmed that Type 2 Kounis syndrome.

\section{Conclusion}

In conclusion, this is the first case defined as Kounis syndrome due to deksketoprofen trometamol. Patients with Kounis syndrome or atopy anamnesis should be carefully evaluated while taking any medicine. If a drug has not been used before by the patient with Kounis syndrome, the first dose should be administrated in hospital.

\section{References}

1. Kounis NG. Histamine-induced coronary artery spasm; the concept of allergic angina. Br J Clin Pravt 1991;45:121.

2. Kounis NG. Koinus syndrome (allergic angina and allergic myocardial infarction): a naturel paradigm. Int J Cardiol 2006;7(110):7-14.

3. Kovanen PT, Kaartinen M, Paavonen T. Infiltrates of activated mast cells at the site of coronary atheromatous erosion or rupture in myocardial infarction. Circulation 1995;92:1084-1088.

4. Toda N. Mechanism of histamine actions in human coronary arteries. Circ Res 1987;61: 280-286.

5. Gázquez V, Dalmau G, Gaig P, Gómez C, Navarro S, Mercé J. J Investig Allergol Clin Immunol 2010;20:162-165. 